\title{
IMPLEMENTATION OF MULTICULTURAL EDUCATION PROCESS IN ISLAMIC INSTITUTE OF FATTAHUL MULUK PAPUA
}

\author{
Sitti Rokhmah ${ }^{1}$ \\ Hamdan Juhannis ${ }^{2}$ \\ Muh. Yaumi ${ }^{3}$ \\ Wahyuddin Halim ${ }^{4}$ \\ Post Graduate Program of Alauddin State Islamic University Makassar, Indonesia ${ }^{1}$ \\ Lecture at The Faculty of Tarbiyah and Teacher Training Alauddin State Islamic \\ University Makassar, Indonesia ${ }^{2,3,4}$
}

\begin{abstract}
This paper examines in depth the implementation of the multicultural education process at IAIN Fattahul Muluk Papua at conceptual and institutional levels. This type of research is qualitative research, the approach used in this research is a multidisciplinary approach with pedagogical, psychological, and sociological approaches. Data sources consist of primary data and secondary data. Data collection techniques through observation, interviews, documentation, literature search and Focus Group Discussion (FGD). The research instrument, namely, the researcher as a key instrument by using the observation theme guide, interview and documentation reference. Processing and data analysis with a model that is condensation Miles and Huberman, data presentation, conclusion and verification. Testing the validity of the data, namely triangulation techniques, checking the correctness of the information, discussing and consulting data, and extending research time. Based on the explanation above, it can be concluded that the implementation of the cultivation of multicultural education values at IAIN Fattahul Muluk Papua through the first conceptual level is realized through planning and formulating the vision, mission, and objectives of IAIN Fattahul Muluk Papua, the second institutional level is implemented through content integration. education in the curriculum) and the internalization of values in learning carried out by stages (a) transforming multicultural values; (b) multicultural value transaction and (c) the application of transinternalization of multicultural values. The three operational levels include curriculum design that is designed based on multicultural values that are applied through the formal curriculum and hidden curriculum (not included in the curriculum) which is unwritten, not programmatically planned but its existence is influential in the application of multicultural education. The four architectural levels are realized through the formation of an adequate and complete multiculturalbased physical environment.
\end{abstract}

Keywords: Multicultural Education

\section{INTRODUCTION}

Conditions for plurality, diversity, and heterogeneity as well as diversity (multiform) society and culture in Indonesia are both a reality and a necessity, long before the formation of the nation-state. This must be honestly acknowledged, 
accepted gracefully, absorbed with full awareness, carefully managed and cared for, and guarded with great joy. It is not rejected, denied, ignored, regretted, ignored and denied just because diversity and diversity have caused negative excesses and critical risks lately, including clashes between communities and local culture in various places in Indonesia. ${ }^{1}$

The present era is an era of multiculturalism where all society and all its elements are required to depend on each other and share their fate for the sake of creating lasting peace. One of the important parts of the consequence of the global order of life which is marked by the diversity of ethnicities, cultures and religions is to build and regain egalitarian attitudes in society. The implications of the global era of multicultural itself for education is how education could present himself if he can educate and produce output that has high competitiveness (qualified) or he is a "dud" in the face of the onslaught of advances era of full competition in various sectors the.

One of the strategic efforts is to build pluralist awareness in the younger generation through education based on multiculturalism. This is by Abudin Nata's statement that Indonesia, with the Pancasila ideology, has a very diverse cultural, ethnic, religious, and economic and social background. Such pluralistic conditions and the heterogeneity of society in Indonesia in turn greatly affect the style of human education. ${ }^{2}$

Education is one of the important keys as an instrument for building human civilization and the nation. Its existence is believed to have a major role in shaping the character of the individuals it educates and is capable of being a "guiding light" for the nation's future generations. This is with consideration, that one of the functions of education is to increase the diversity of students with their own religious beliefs and to provide the possibility of openness to studying and questioning other religions to the extent of fostering tolerance.

So far, in Indonesia, education at a macro level has not shown the expected results because of several things that need to be improved and changed; the philosophy of education seems very positivist, pragmatic, developmental, industrialist, indoctrinate, uniformity and monocultural. This kind of educational philosophy can no longer be maintained and must be changed with an ideal education philosophy for Indonesia, namely, idealistic, holistic, liberating, intellectualistic, pluralistic, and multicultural. ${ }^{4}$

${ }^{1}$ Rasiyo, Berjuang Membangun Pendidikan Bangsa; Pijar-pijar Pemikiran dan Tindakan (Cet. I: Malang: Pustaka Kayu Tangan, 2005), h. 47.

${ }^{2}$ Abudin Nata, Pidato Pengukuhan Guru Besar (Pendidikan Islam di Indonesia: Tantangandan Peluang)(UIN Syarif Hidayatullah Press), h. 1.

${ }^{3}$ Syamsul Maarif, Islam dan Pendidikan Pluralisme; Menampilkan Wajah Islam ToleranMelalui Kurikulum PAI Berbasis Kemajemukan, in Annual Confrence di Lembang Bandung, source www.google.com/pluralisme-pendidikan, access of 22 November 2018.

${ }^{4}$ Rasiyo, Berjuang Membangun Pendidikan Bangsa; Pijar-pijar Pemikiran dan Tindakan, h. 47. The purpose of the positivist philosophy, namely the educational paradigm that overrides the diversity of student potentials, pragmatic means concerned with results rather than processes, developmentcentric, educational industrialists only print industrial robots, tend to homogenize students and single out diversity. The essence is that philosophy the absence of an educational soul eye towards human nature and this educational philosophy must be changed to be based on lofty ideals (ideal), holistic 
Islamic education is challenged to answer the challenges of the times, among others: First, how it can increase sustainable development. Second, how Islamic education can carry out comprehensive research on the occurrence of the reform era with the transformation of the social structure of society, from traditional-agrarian society to modern-industrial and reform-communication society, and how to develop Human Resources (HR). Third, how Islamic education increases quality creative competitiveness as a result of thought, discovery and mastery of science, technology and art in global competition. Fourth, how Islamic education can face challenges to the emergence of colonialism innovation in the political and economic fields. ${ }^{5}$ In addition, the most pressing challenge for Islamic education is multicultural globalization which is very prone to division and dehumanization, so the application of education that uses a multicultural approach is important. ${ }^{6}$

Higher education institutions that have a tri dharma task, of course, also carry the mandate to carry out multicultural education. Likewise, with the State Islamic Institute (IAIN) Fattahul Muluk Papua which has just transformed from high school. In the field of education it is clear that the task of carrying out multicultural education and teaching is his responsibility. Likewise with research activities and community service in the multicultural field. As a higher education institution, the roles in carrying out multicultural education must be carried out in the tri dharma of higher education.

The very diverse cultural spectrum of the Papuan people is indeed a challenge for the world of education, especially in Papua, to cultivate how these differences can be used as assets, not a source of divisions that lead to the disintegration of the nation. In this era of globalization, multicultural education has a dual-task, namely in addition to uniting the nation itself which consists of various kinds of cultures to coexist or live in togetherness, it must also prepare the Indonesian nation to be ready to face the flow of foreign cultures entering this country.

Through this method or strategy, education, especially multicultural education, can play a role in preventing conflicts between cultures, races and religions and even conflicts that lead to disintegration. If we look at intercultural meetings in the era of globalization, this could be a serious threat to our students. So in this connection students need to be given awareness of diverse knowledge, so that they have global knowledge competencies, including aspects of culture.

This paper examines in depth the implementation of the multicultural education process at IAIN Fattahul Muluk Papua at conceptual and institutional levels.

\section{THEORETICAL STUDY}

Juridically, Law No. 20 of 2003 concerning the National Education System has hinted at a multicultural education concept. Article 4 paragraph 1 of Law No. 20 of 2003 states that education is carried out in a democratic and just manner and is not

(holistic), freeing exploration of potential (liberative), prioritizing intellectuality, respecting diversity and cultural diversity as well as student characteristics.

${ }^{5}$ Armai Arief, Reformulasi Pendidikan Islam, (Jakarta: C3RD Press, 2005), h. 6-7. Lihat pula Armai Arief, Tantangan Pendidikan di Era Global, dalam Jurnal Institut, NO. I, thn. 2005, h.33

${ }^{6}$ Abudin Nata, Paradigma Baru Pendidikan Islam di Era Pasar Bebas, dalam Didaktika Islamika, Jurnal Kependidikan, Keislaman dan Kebudayaan, Vol. 1, Januari 2015, h. 42. 
discriminatory by upholding human rights, religious values, cultural values, and national diversity.

The diversity in the IAIN Fattahul Muluk Papua campus is used as the basis for choosing a pattern as a model for the meaning of developing multicultural values. The implementation of planting multicultural educational values is implemented at the conceptual level and institutional level.

First, the conceptual level, the implementation of education multicultural values in college can be seen from the formulation of the vision, mission, and purpose of the college, the Second level of institutional, implementation of value investment multicultural education is realized through (1) the integration of the value of learning by grand theory by Banks explains the dimensions that must exist in the formulation of multicultural education, namely the integration of education in the curriculum (content integration) which involves diversity in an educational culture whose main purpose is to eradicate prejudice. ${ }^{7}$ and (2) internalization of values in learning according to Muhaimin is carried out through three stages, namely (a) value transformation; (b) value transactions; (c) and value transinternalization. ${ }^{8}$ The three operational levels in its implementation include curriculum design that is formulated in such a way as to implement multicultural education in learning. According to Yuyun Nurhidayati, multicultural education is manifested in a curriculum that accommodates diversity, cultural changes, and teaching techniques and minimizes discrimination in the form of race, suspicion and prejudice for all citizens in a multicultural society, which can be carried out in two models, namely the formal curriculum and hidden curriculum (not included in the curriculum). ${ }^{9}$ The four architectural levels of implementation of the inculcation of multicultural education values are realized through the formation of a physical environment such as complete multicultural based facilities and infrastructure. $^{10}$

Application of multicultural values in education gave birth to multiculturalism is the understanding of cultural diversity and the diversity that is embedded in the minds, attitudes, and behaviors in themselves students of the value of tolerance, the value of pluralism, the value of democratic values in common, the values of justice, the value of empathy, and humanist. ${ }^{11}$ With this theoretical framework, it is hoped that it can provide direction in the formulation of methodological steps that will be carried out by researchers.

\section{III.RESEARCH METHODOLOGY}

This type of research is qualitative research, the approach used in this research is a multidisciplinary approach with pedagogical, psychological, and sociological approaches. Data sources consist of primary data and secondary data. Data collection

${ }^{7}$ James A. Banks, Multiccultural Education: Historical Development, Dimension, and Practice, dalam Handbook (San Fransisco: Jossey-Bass, 2015), h. 29

${ }^{8}$ Muhaimin, Strategi Belajar Mengajar(Surabaya, Citra Media, 1996). h. 153.

${ }^{9}$ Yuyun Nurhidayati, Multicultural Education in America (Yogyakarta: Universitas Gajah Mada), h. 221.

${ }^{10}$ Yuyun Nurhidayati, Multicultural Education in America, h. 225

${ }^{11}$ Ainul Yaqin, Pendidikan Multikultural: Cross-Cultural Understanding untuk Demokrasi dan Keadilan (Yogyakarta: Pilar Media, 2015), h. 6-9. 
techniques through observation, interviews, documentation, literature search and Focus Group Discussion (FGD). The research instrument, namely, the researcher as a key instrument by using the observation theme guide, interview and documentation reference. Processing and data analysis with a model that is condensation Miles and Huberman, data presentation, conclusion and verification. Testing the validity of the data, namely triangulation techniques, checking the correctness of the information, discussing and consulting data, and extending research time.

\section{IV.RESULT AND DISCUSSION}

The implementation of multicultural education in learning at IAIN Fattahul Muluk Papua is carried out through four levels of implementation, namely: (1) the conceptual level; (2) institutional; (3) operational; and (4) architectural.

\section{a. Conceptual Levels}

At the conceptual level, the implementation of multicultural education in learning at IAIN Fattahul Muluk Papua is realized through planning and formulating the vision, mission and objectives of IAIN Fattahul Muluk Papua. The vision of IAIN Fattahul Muluk Papua is "The realization of IAIN Fattahul Muluk Papua which is dynamic, has a global perspective, multiculturalism, and has an Islamic spirit, Rahmatan il a 'lamin in $2025 .^{12}$

Noting the vision of IAIN Fattahul Muluk Papua, it has a very ideal concept in implementing the cultivation of multicultural educational values, this is stated in the vision of IAIN Fattahul Muluk Papua. To clarify, it is necessary to analyze each word contained in the visit, namely:

First, the word dynamism refers to the existence of IAIN Fatahul Muluk which always moves forward and adapts to the standards of good governance, both in terms of human resources and institutional management. Dynamic also means that IAIN can adapt to any changes and developments in science and technology, as well as the demands and needs of stakeholders.

The two words with global insight indicate the level of knowledge of the academic community, especially graduates of IAIN Fatahul Muluk, not only at the local and national levels but covering the development of various aspects of life at the global level. The point is to understand the development of the world of civilization comprehensively, with that insight the IAIN institution can be dynamic according to the times and determine the target of competitive graduates.

The three words multicultural mean that IAIN Fatahul Muluk as a state Islamic religious university does not have an exclusive attitude in developing science, religion, art and technology. Multiculture becomes the framework for organizing the tri dharma of higher education, so that the existence of IAIN not only provides benefits to Muslims, but also to all residents in Papua through research and community service activities.

Fourth Islam rahmatan lil a 'lamin meaning of Islam as a mercy to the worlds (rahmatan lil aalamin) into the soul IAIN Fatahul Muluk in exercising its functions tri dharma college. In the context of Papua, IAIN Fatahul Muluk is a blessing for Papua, which is to provide benefits to all of Papua.

\footnotetext{
${ }^{12}$ Renstra IAIN Fatahul Muluk 2018-2023, h.9.
} 
Taking into account the vision of IAIN Fatahul Muluk Papua, it can be assumed that the implementation of multicultural education values that are embedded in the conceptual level depicts the campus as a campus that upholds multicultural values, has a strong concern for the development of these positive social attitudes. Thus, multicultural education rejects social attitudes that tend to be racial, stereotypical (mocking certain objects) and prejudice against other people or groups of different ethnicity, race, language, culture and religions.

The IAIN Fatahul Muluk Papua campus is conceptualized in its view of acceptance, recognition, and appreciation of diversity like a mosaic in a society. The mosaic includes all the cultures of the smaller societies (microculture) which shape the creation of a larger society (macroculture).

While the mission of IAIN Fattahul Muluk Papua is a) Organizing and developing an education system that integrates Islamic values, culture, and globalization; b) Improve the quality of research that is beneficial for scientific interests oriented towards Islam and plurality; c) Carry out community service-oriented towards community development in the socio-religious field; and d) Build trust, and develop cooperation with trusted national and international institutions in the fields of education and socio-religion. ${ }^{13}$

Noting the mission of IAIN Fatahul Muluk Papua, it also contains a very special concept to implement the cultivation of multicultural education values starting from the first point to the fourth point, all of which lead to the cultivation of multicultural educational values, such as the word integrating Islamic values, culture and globalization. In essence, Islamic values have a close relationship with multicultural values according to the results of an interview with the Chancellor of IAIN Fatahul Muluk Papua as follows:

"In the mission of IAIN Fatahul Muluk Papua, religious and multicultural values are written because Islamic values have a close relationship with multicultural values, for example, the concept of equality, the concept of justice, the concept of independence, and the concept of tolerance (tasamuh), and the concept of an attitude of acknowledging, accepting, and respecting diversity. All these concepts are included in the values of Islamic teachings and include the values of multicultural education, which is why these values are always juxtaposed on this campus." 14

First, the concept of equality/equality includes the values of Islamic teachings and includes the values of multicultural education which view humans as basically the same as the same. The only qualitative distinction in the Islamic view is piety. So this concept also applies to both men and women, they are the same in God's eyes.

According to Islam, all humans come from the same origin, namely the Prophet Adam and Eve. Even though their ancestors were the same, in their development they later split into tribes, clans, or nations, complete with all the cultures and civilizations that were unique to each. In multicultural values, they must remain close to each other, know each other, and respect each other in social interactions.

2019.

\footnotetext{
${ }^{13}$ Renstra IAIN Fatahul Muluk 2018-2023, h. 9

${ }^{14}$ Idrus Al-Hamid (47 th), Rector of IAIN Fattahul Muluk Papua, Interview, Jayapura, 11 Mei
} 
The two concepts of justice are the basis for the values of Islamic teachings and include the values of multicultural education which mean equal recognition and treatment of rights and obligations. If you recognize the right to life, then you are obliged to defend the right to live by working hard without harming others. Because other people also have the right to live. If we also recognize other people's right to life, we are obliged to give opportunities to other people; we are obliged to give opportunities to other people to defend their right to life. So, justice lies in the balance or harmony between claiming rights and carrying out obligations. The fair must be done to oneself, family and group.

The three concepts of independence, as part of the values of Islamic religious teachings and including the values of multicultural education, see that all human beings are essentially only servants of God, not at all servants of fellow humans. Rooted from this concept, humans in the view of Islam have the freedom to choose a profession, choose a hobby or interest, choose a living area, and even in making religious choices, they cannot be forced.

The four concepts of tolerance (tasamuh) are the values of Islamic teachings and include multicultural education values which are the attitude of allowing, acknowledging and respecting the beliefs of others without requiring approval. Arabic translates the word "tasamuh", which means to allow each other, to facilitate each other.

The five tolerances mean permitting, allowing what in principle need not happen. If tolerance contains concessions, that means giving based only on generosity and kindness, not based on rights. It is clear that tolerance occurs and applies because there are differences in principles, and in respecting the differences or principles of others it should be without sacrificing one's principles. Besides that, tolerance is also an attitude of accepting that other people are different from us. Dialogue and tolerance are an inseparable unity. If dialogue is the form, tolerance is the content.

The six concepts of the attitude of recognizing, accepting, and respecting diversity are the values of the teachings of the Islamic religion and include the values of multicultural education, the attitude of accepting, acknowledging, and respecting this diversity which is necessary for social life in a pluralistic society. Meanwhile, acceptance, recognition, and respect for diversity are social attitudes needed in building harmonious social relationships in a pluralistic society.

The objectives of IAIN Fattahul Muluk Papua Papua are a) To implement an education system that integrates aspects of Islamic values, culture and globalization; b) The implementation of quality research which is beneficial for scientific interests oriented towards Islam and plurality; c) Implemented community service that is oriented towards community development in the socio-religious field; and d) To establish cooperation with trusted institutions both nationally and internationally in the fields of education and socio-religion. ${ }^{15}$

In a multicultural era like now, IAIN Fatahul Muluk Papua is very apt to position itself as a university that applies the values of multicultural education and designs ideal concepts so that IAIN Fatahul Muluk Papua becomes a media in forming positive attitudes towards various social realities. This concept is contained in the vision, mission, and objectives of IAIN Fatahul Muluk Papua so that it gives birth to attitudes and understanding to accept, acknowledge and respect other people with various backgrounds. Because other people, regardless of their creed and religion, are

\footnotetext{
${ }^{15}$ Renstra IAIN Fatahul Muluk 2018-2023, h. 14.
} 
God's people who have the same right to live on God's earth. The inculcation of inclusive attitudes and values will later become the main bargaining power in the multicultural education system, especially in Islamic education.

The teachings of Islam and the value of multicultural education have significant potential in directing students to tolerant views or vice versa. Besides, the values of Islamic teachings and the values of multicultural education contained in the vision, mission and objectives of IAIN Fatahul Muluk Papua have strong potential to realize unity. All of these potentials are influenced by many factors, such as environment, religious understanding, the influence of religious leaders or lecturers in conveying the values of Islamic religious teachings and the value of multicultural education, and the views of religious followers of theology or religious doctrines.

The motto of IAIN Fatahul Muluk Papua is "Religious, Multicultural, and Value Transformation". Of the three basic values, it can be seen the conceptual level, the integration of multicultural value education. The Basic Values of IAIN Fatahul Muluk Papua, which form the basis of IAIN Fatahul Muluk Papua, are Religious, Multicultural, and Value Transformation. Religion becomes attitude and behavior, this attitude is manifested inclusively in seeing all the differences that exist in society, and therefore multicultural becomes the second Basic Value. In developing the vision of rahmatan lil aalamin, IAIN Fatahul Muluk Papua is not only multicultural but also carries out a Value Transformation of Islamic teachings in the contemporary context.

The first basic value is religious, which is an attitude, behavior, and mindset based on the values of Islamic teachings (al-Quran and Hadith) so that faith and devotion to Allah SWT are the only way.

The second basic value Multiculture is a blessing for all nature (rahmatan lil aalamin). For IAIN Fatahul Muluk Papua, the value of rahmatan lil aalamin is translated into "IAIN Fatahul Muluk as a blessing for Papua", therefore IAIN Fatahul Muluk highly appreciates, respects, and recognizes all forms.difference as a reality that exists in Papua and is not exclusive. This thinking is the second basic value of IAIN Fatahul Muluk Papua, namely multicultural.

IAIN Fatahul Muluk Papua lays down concepts and doctrines that give blessings to al-'alamin. IAIN Fatahul Muluk Papua implements Islamic teachings as teaching that contains normative values, full of teachings that respect the pluralist-multicultural dimension so well in viewing and placing human dignity and dignity, both as individuals and as social members.

The third basic value is value transformation, which means that the values of Islamic teachings as in al-Quran and Hadith are transformed in the contemporary context, except for things that have been explicitly stated, either compulsory or prohibited. The choice of the principle of value transformation as a basic value is due to a belief that Islam will always be by the times, both in the past, present, and in the future, both in this world and in the hereafter.

The value transformation is intended so that the existence of IAIN Fatahul Muluk provides benefits to the pluralistic life of the people in Papua, as well as embodies the values of Islam as a religion that is peaceful, tolerant, and supports progress for the happiness of all mankind. Therefore, the educational model developed by IAIN Fatahul Muluk is not making a dichotomy between science (science) with religion but combined into a single unit. This value rests on the belief that Allah SWT elevates the rank of those who believe and have knowledge. Furthermore, the vision of 
the institution is derived into the vision of each faculty as an implementing unit following the chosen program.

The condition of the education situation in Papua is also marked by several educational problems such as parents 'dissatisfaction with the acceptance and placement of the desired learning place/school, sometimes parents' dissatisfaction with reports of learning outcomes from teachers and the learning process at school and several other cases that tend to be resolved through violence. . Parents bully the teacher when the teacher does not graduate their child in a school, for example, it often happens. These conditions are conveyed to prospective teacher students so that they will be ready to face conditions in society.

From the above reality, the problems of society in Papua are anticipated by implementing multicultural education in learning as an educational process for a way of life to respect, sincerely, tolerate cultural diversity that lives during a plural society, so that students will have a mental character of the nation in responding to conflicts. Understanding and awareness of multicultural realities through education at all levels of education, especially at IAIN Fattahul Muluk Papua, certainly have a concrete impact on the life of the community at large in the future.

The application of multicultural education at IAIN Fattahul Muluk Papua in learning is an unavoidable alternative solution. The application of multicultural education at IAIN Fattahul Muluk Papua is education that provides equal opportunities to all children of the nation regardless of treatment due to differences in ethnicity, culture, and religion and requires the highest human respect and respect for human dignity from whatever cultural background. In the Indonesian context which is full of diversity, this education has a very strategic role to be able to manage this diversity creatively. The offer is through the application of multicultural education at IAIN Fattahul Muluk Papua.

Taking into account the formulation of the vision, mission, and objectives of IAINFattahul Muluk Papua above, it can be assumed that at IAIN Fattahul Muluk Papua has been planned in the application of multicultural education. Graduates are expected to be people who have (1) spiritual depth; (2) the greatness of akhlak; and (3) become a driving force for society.

First, students have spiritual depth, this is part of their seriousness in the application of multicultural education at IAIN Fattahul Muluk Papua which is an effort to develop, encourage and invite people to be more advanced based on high values and a noble life so that a more perfect person is formed, whether related to reason, feelings, or actions based on the values of Islamic teachings.

The purpose of having spiritual depth is an educational system that includes all aspects of life that are needed by humans. This educational system is then understood and developed based on the fundamental values of Islamic teachings, namely al-Quran and hadith and manifested in the form of multicultural educational ideas and theories.

Second students have the greatness of akhlak which is reflected as an institution that has the concept of implementing multicultural education at IAIN Fattahul Muluk Papua because it develops the ability to control the actions needed so that a person can truly understand the moral decisions he takes, can identify good reasons that must be accepted and reasons that are not good which must be rejected or changed. In the end, students must be able to formulate changes that need to be made based on the values of Islamic teachings. 
The greatness of ahklak as a form of concept that is built in the application of multicultural education at IAIN Fattahul Muluk Papua students have a simple and straight attitude, moderate attitudes are not exaggerated, are good at behavior, are humble, knowledgeable, do honest deeds, keep promises, trust, istiqamah, willing, courageous, patient, grateful, gentle, and others. is implied:

The greatness of ahklak possessed by IAIN Fattahul Muluk Papua students

1. In the pattern of relationship to Allah as recognition and awareness that nothing God except Allah. Morals towards Allah are a form of human servitude as creatures, to God as the creator. The actualization of the morals of a servant to Allah can be seen from the knowledge, attitude, behavior and lifestyle that is filled with the awareness of tawhid to Allah, this can be proven from the act of righteous deeds, devotion, obedience, and sincere worship of Allah.

2. Morals towards fellow humans, meaning that IAIN Fattahul Muluk Papua students have social attitudes towards other people. Regarding this, the form of prohibition is not only to do negative things such as killing, hurting the body, or taking property without the right reasons, but also hurting one's heart by telling someone's shame behind him is also not allowed.

3. Students of IAIN Fattahul Muluk Papua have morals towards the environment, which is meant by morals towards the environment, be it the surrounding natural environment or other inanimate objects the morals recommended by the Al-Qur'an for the environment are derived from the function of humans as caliphs. What has implied in daily life the value of Islamic teachings to their environment, for example, students are given an understanding and practice that it is not right to take fruit before it is ripe, pick flowers before blooming, and damage the environment by littering and so on.

The three students become the driving force for society; it is a form of multicultural-based planning because the planning to be achieved in learning creates $a$ social setting that allows the implementation of the knowledge gained to solve problems in society. This is following the essence of multicultural education in the concept of the vision, mission, and goals of IAIN Fattahul Muluk Papua, namely education for people of color. That is multicultural education wants to explore differences as a necessity of a gift from God Almighty so that students can respond to this with tolerance and an egalitarian spirit.

In the concept of the vision, mission, and goals of IAIN Fattahul Muluk Papua Students IAIN Fattahul Papua Muluk able to live in an atmosphere of diversity (pluralism/multiculturalism) and trying to avoid interactions that can lead to disharmony and the rift. Based on general observation, students of IAIN Fattahul Muluk Papua have never been involved in actions such as demonstrations held by student association forums. Instead, they are active in carrying out activities in social action.

In planning and formulating the vision, mission, and objectives of IAIN Fattahul Muluk Papua in all faculties as a reference for the implementation of planting multicultural education values because, in the vision, mission and objectives, they include multicultural values that form a generation that has high nationalism towards 
their traditions and beliefs. , as well as having the will and sufficient intellectual ability to maintain this tradition from generation to generation, also being able to accept, acknowledge and appreciate the existence of different traditions and beliefs as world cultural wealth. This is the essence of the output offering of the multicultural education system IAIN Fattahul Muluk Papua which contained in its conceptual level.

\section{b. Institutional Stage}

Institutionally, the implementation of the inculcation of multicultural educational values at IAIN Fattahul Muluk Papua is realized through the formation of an institutional culture that reflects the combination of multicultural values with lecture material in the learning.

To find out more deeply at the institutional level in the application of multicultural education at IAIN Fattahul Muluk Papua, it is implemented through (1) integration of values in learning; and (2) internalization of values in learning. To get more accurate data about the implementation of multicultural education at IAIN Fattahul Muluk Papua which is applied through the tri dharma of higher education in education and teaching. Researchers collected data through observation, interviews, and document analysis on the learning process at IAIN Fattahul Muluk Papua by describing the two dimensions mentioned above, as follows:

\section{Integration of Value in Learning}

The integration of values in learning at IAIN Fattahul Muluk Papua has been applied based on the principle of multicultural education which is applied to all types of subjects by using cultural differences that exist in students and communities around the IAIN Fattahul Muluk Papua campus, such as giving students an understanding of the nature of ethnic differences, religion, language, gender, social class, race, ability, and age so that the lecture process becomes effective and easy to apply in everyday life.

In implementing the integration of multicultural values in learning at IAIN Fattahul Muluk Papua, several values are integrated, namely (1) the value of tolerance; (2) the value of pluralism; (3) Democratic values; (4) Human values (humanist).

In this regard, the researcher interviewed with one of the Akidah Akhlak lecturers at the Tarbiyah Faculty of IAIN Fattahul Muluk Papua as follows:

"In learning Akidah Akhlak that I develop, I try to implement multicultural education through integration in lecture materials that give students understanding to know, acknowledge, assess, respect, and tolerate the diversity of religions, cultures, gender, social class, race, abilities, and age. Found in a pluralistic society. Discussions that take up themes that exist in society, in fact, give a real picture for students to be harmonious in this life. Alhamdulillah, the integration of multicultural education into student lectures can respond to and provide solutions to social conflicts that often occur in society. In particular, the integration of social values is implemented in the classroom."

For the data from the interviews to be more accurate, the researchers continued their observations in several classes at the Tarbiyah faculty. The results of the

\footnotetext{
${ }^{16}$ Atinah Rahmah (35th), Lecturer of Akidah Akhlak Fakultas Tarbiyah IAIN Fattahul Muluk Papua, Interview and Discussion, Jayapura, 9 Mei 2019
} 
observations illustrate that the students of the Tarbiyah Faculty of IAIN Fattahul Muluk Papua have the value of social concern which is manifested through class fees, which are collected and intended for joint activities in that class. Besides, along with other classes, they often conduct social fundraising actions for friends who are sick, grieving and who need help by distributing charity boxes from class to class.

Researchers interviewed students as follows:

"Alhamdulillah, as a student, he also tries to apply the value of social care. For example, instilling a sense of care for fellow students if there are students who do not enter, because they are sick, their parents or their families are affected by a disaster, the lecturers and students pray for it together. Besides, if someone gets into trouble (grief, disaster), the lecturer in addition to leading the prayer, the lecturer also gives generous funds and encourages the class leader to care for friends who are in trouble through solidarity actions by raising funds. Then the funds are given to the person concerned as a sense of care and empathy. ${ }^{17}$

Lecturers always integrate the value of social care that does not differentiate between race and ethnicity. Usually by understanding the verses of the Koran about the command to support the weak (dhuafa), and learn about the nature of righteous deeds. The manifestation of understanding of the holy book then emerges awareness when a student or his family gets a disaster by praying, visiting or ta'ziyah and providing moral and material assistance to the family concerned."

The observation results also illustrate that students grow democratic values in the classroom through lectures in several study programs at the Tarbiyah Faculty. Both lecturers and students alike instill a democratic spirit which is an important tool in the lecture system. Lecturers teach by applying existing rules or guidelines, except for some technical matters that have not been stated in the rules. Students are also the same, for example when they elect the class leader they to deliberate based on a democratic consensus. Learning democracy is evident among students. They are very united and united in their class. Classroom devices are turned on and on, to make learning comfortable.

Based on descriptions of interviews with Akidah Akhlak lecturers at the Tarbiyah Faculty of IAIN Fattahul Muluk Papua, they have implemented the integration of cultural values in learning so that they become the most effective media to produce a generation that has a view that can make this diversity a part that must be appreciated constructively.

The integration carried out in learning at the Tarbiyah Faculty of IAIN Fattahul Muluk Papua is very appropriate as a solution to facing a multicultural-multireligious nation and society, socio-religious issues are not simple problems. The complexity of social relations between religious communities is felt by all elements in society, from politicians, lecturers, religious leaders and parents at home. Because in a multicultural view, each has the same rights, each has a way to maintain their traditions and identity in various ways that can be done.

The integration of multicultural values in learning at IAIN Fattahul Muluk Papua is a learning strategy that makes the various cultural backgrounds of students

\footnotetext{
${ }^{17}$ Ahmad Furqon, Student of IAIN Fattahul Muluk Papua, Interview, Jayapura, 19 Mei 2019

${ }^{18}$ Sella Rahmawati, Student of IAIN Fattahul Muluk Papua, Interview, Jayapura, 19 Mei 2019
} 
designed to support and expand the concepts of culture, difference, equality, democracy, equality and justice-oriented towards humanity, togetherness, and peace, and develop attitudes to recognize, accept and appreciate diversity based on multicultural principles.

In the freelance discussions that were deliberately carried out by researchers about the integration of values in learning, the researcher indirectly asked several young lecturers to analyze how to realize the IAIN's vision and mission in learning? In general, they answered that we have integrated the values of multicultural education, by indirectly including the spirit of these values in the learning process, for example, the attitude of how to accept the diversity of learning methods among students in the class, accepting the various habits that are brought in daily interactions their day, including how the lecturers can accept the diversity of patterns of interaction in learning that are motivated by the habits of their respective origins.

About what has been explained above, the researcher conducted interviews with IAIN Fattahul Muluk Papua students as follows:

"In my opinion, almost all lecturers, if they provide lecture material, always integrate courses with Islamic religious values because all are in line with multicultural values. The integration of multicultural values is part of the implementation of multicultural education that is applied to this campus. The existence of the integration of multicultural values in lectures already exists in Islamic teachings so that indirectly these values have been integrated long ago in learning before the emergence of multicultural education discourse, for example, concepts, justice, freedom and tolerance in multicultural education have been manifested in several courses on this campus."19

The results of interviews with IAIN Fattahul Muluk Papua students illustrate the application of the integration of multicultural values in learning based on a national context that recognizes cultural diversity, differences and pluralism, both race, ethnicity, ethnicity and religion. The application of the integration of multicultural values in learning at IAIN Fattahul Muluk Papua provides understanding and planting to students that plural or pluralistic nation is a nation filled with diverse cultures (multicultural).

This level of values is part of the dimension of Islamic education (Al-tarbiyyatu al-Islamiyyah). In Islamic education, an important role will be found in fostering education in the family, community, and educational institutions that touches three aspects of education, namely aspects of the body, mind, and heart.

The integration or integration that is carried out in learning at IAIN Fattahul Muluk Papua is a process that is experienced in accepting and belonging to him various attitudes, ways of expressing feelings or emotions, fulfilling desires, desires, passions, beliefs, norms of values as owned by other individuals in the group. The process of integrating Islamic and multicultural values is carried out in everyday life and must be made part of the student's personality because all multicultural values are presented directly in the classroom.

This is by the results of interviews with lecturers at the Tarbiyah faculty as follows:

"In my opinion, it must be even mandatory for all lecturers to integrate multicultural values in lectures. In lecture activities to instill to all students the importance of tolerance (respect for others) and having social concern. The

\footnotetext{
${ }^{19}$ Warsan (37th), Student of Postgraduate Islamic Studies, Interview, Jayapura, 17 Mei 2019
} 
lecture approach puts forward the andragogy learning system (adult education). In lectures, students are trained to respect others, either individually or in groups through paper presentations or other activities. In this PAI department, students tend to be homogeneous in terms of culture, while in terms of gender and socioeconomic backgrounds, they are also different.",20

The researcher made observations in the class where the researcher taught. Besides that, he also saw several other classes during the recovery process. The results of the observations show that in lecture activities, students appear to be tolerant of mutual respect in respecting opinions, such as when discussing papers. Even though there are differences of opinion, they are presented with polite arguments and logical empirical facts. It is rare for an argument to take place that leads to emotion and tension but appears in an atmosphere of fairness.

Tolerance is a very noble value of Islamic teachings and multicultural education. In general, the tolerance instilled in IAIN Fattahul Muluk Papua appreciates diversity as the fruit of tolerance that starts with thoughts, is reflected in attitudes, and manifests in behavior.

This is in line with the presentation of an interview with an IAIN Fattahul Muluk Papua lecturer, as follows:

"The integration of religious values and multicultural education values is directly applied in the classroom during lectures. For example, I always emphasize tolerance. In the value of tolerance, tolerance is instilled in mind, tolerance in attitude, and tolerance in behavior.",21

The results of the interview integrated Islamic religious values and multicultural education values in terms of tolerance with the concept of tolerance in mind, namely positive thinking towards those who are different, among others due to different religions, ethnicities and cultures, because Allah created people with different ethnicities, races. The lecturer emphasized the students' tolerance in attitude, namely having a good attitude towards anyone who is not the same as ourselves, for example, ethnicity, race and nation, and also instilled in students tolerance manifested in behavior, namely acting fairly towards anyone without hatred and hostility.

In lecturing activities, the lecturer does not differentiate between students being taught based on ethnicity, race, class, social status and economy. Lecturers respect by providing learning opportunities according to their respective cultures and creativity. The concept of multicultural value is integrated with experiences in social life. Moral thinking can be developed, among others, with social dilemmas that require the ability to make decisions in very dilemma situations. Actions that are in harmony with multicultural thinking are only possible through emotional and spiritual intelligence and habituation.

It can be seen in the results of observations that students at IAIN Fattahul Muluk Papua have a social concern in lecture activities which are manifested in ways such as learning together (cooperation), helping each other. Students who have laptops, for example, use the tool together for presentations and access some of the information their

\footnotetext{
${ }^{20}$ Talabudin Umkabu (45 th), PAI Lecturer of IAIN Fattahul Muluk Papua, Interview, Jayapura, 18 Mei 2019

${ }^{21}$ Husnul Yaqin (45 th), Shari'ah Lecturer of IAIN FAttahul Muluk Papua, Interview, Jayapura
} 20 Mei 2019 
team needs. This is especially so when the researcher himself teaches a class in Education Statistics which requires a laptop. Not all students have laptops, and it is also not possible to study in a computer laboratory. They are neither selfish nor stingy, which has the advantage of helping those who do not have adequate college equipment.

The application of multicultural value integration in learning at IAIN Fattahul Muluk Papua provides support for its social development even though it does not eliminate student identity, where each student has an identity. In psychology, the concept of identity generally refers to an awareness of the unity and continuity of the person, as well as a belief that is relatively stable throughout the life span, despite changes.

The application of integration of multicultural values in learning at IAIN Fattahul Muluk Papua becomes a multicultural education transformer that instills the values of pluralism, humanism, and democracy directly on campus to students according to an interview with one of the lecturers of the PAI program at the postgraduate program of IAIN Fattahul Muluk Papua as follows:

"In learning on campus, we have implemented multicultural value integration by instilling values of tolerance, empathy, sympathy, and social solidarity in classroom learning so that students who are democratic, pluralist, humanist have been formed, to overcome conflicts and create national peace. Especially for these postgraduate students who on average are teachers. They directly touch each day with students in various schools. This is where the practice of value integration must be developed and developed." 22 .

Furthermore, observations in the classes to obtain authentic data related to democratic values. Each class has a class leader who is in charge of conveying matters related to the interests of learning in their class and other matters related to the coordination of other activities. They form a forum. The forum is facilitated to hear directly from class representatives various problems and complaints related to lectures. There are many benefits from the class forum activities, such as how active the lecturers are in carrying out their duties, noting technical problems in lectures, to suggestions for improving services to students. A democratic and togetherness atmosphere is built to provide shared learning. Students and lecturers can correct each other, to create an optimal ideal atmosphere. No stratum is more dominant, let alone authoritarian in lecture activities. Both lecturers and students understand their duties and responsibilities, their rights and obligations.

The application of multicultural value integration in learning at IAIN Fattahul Muluk Papua instills the characteristics of multicultural education based on democracy, equality and justice which provides equal opportunities to obtain the right to life, the right to equality, and education. The application of multicultural value integration in learning at IAIN Fattahul Muluk Papua is not only limited to providing equal opportunities to all children to get an education but also means that all children get the same treatment to get lessons in educational institutions.

Implementation of the integration of the value of multicultural learning in IAIN Fattahul Muluk Papua every student receives the same treatment regardless of their differences in background, color, culture, ability, age and gender because the orientation

${ }^{22}$ Husnul Yaqin (43 th), Lecturer of IAIN Fattahul Muluk Papua, Interview, Jayapura, 18 Mei 
of the value of multicultural education-oriented humanity (humanity) are understood and implemented as a value that places the enhancement of human development, existence, and dignity as the highest human thought and action.

The application of multicultural value integration in learning at IAIN Fattahul Muluk Papua is oriented towards togetherness (co-operation). Togetherness here is understood as one's attitude towards other people, or one's attitude towards groups and communities, so that in its application it applies the multicultural value integration method, as put forward by one of the lecturers at the postgraduate program of theIAIN Fattahul Muluk Papua as follows:

"In the application of multicultural value integration in classroom learning that is carried out in integrating Islamic values and multicultural values in learning through multiple intelligence approaches and interdisciplinary approaches. When carrying out the learning process, students are facilitated by lecturers by paying attention to all aspects of intelligence, talents, interests and personality. We as lecturers appreciate every statement, question and answer that is put forward by students in every lesson, especially in discussions in this master class." 23

Direct involvement or experience in learning through direct student experience is not only observing but also experiencing and being directly involved in actions and being responsible for the results. Student involvement in the learning process is not limited to physical involvement, but more than that it is mental-emotional involvement, involvement with cognitive activities in the attainment and acquisition of knowledge, involvement in the appreciation and internalization of values informing multicultural attitudes and values.

Based on interviews with several professors envisaged that the implementation of the integration of the value of multicultural learning in IAIN Fattahul Muluk Papua in the classroom apply via some models even through integrated learning model models integrated are simultaneously on the learning of all subjects, all activities of student guidance integrated value of multicultural in classroom learning.

However, it is realized that starting the implementation simultaneously is not easy. The condition of human resources and other resources greatly affects the readiness to implement the value of multicultural education. The implementation of multicultural education values at IAIN Fattahul Muluk Papua is carried out in an integrated manner and starts from several courses and several student activities in the classroom.

Based on interviews and observations above, indicates that the application of religious values and multicultural integration in learning in Papua Muluk Fattahul IAIN run properly oriented to peace (peace). Peace is the ideal of all people who live in a heterogeneous society. Peace in a society can be realized by avoiding violence, wars and acts of selfishness, and by presenting justice and respecting the opinions of others. face a multicultural nation is a nation that group-ethnic or cultural (ethnic and cultural groups) that there can coexist peacefully in the principle of co-existence marked by a willingness to respect other culture until students realize the importance of building a harmonious life in the absence of hostility, conflict, violence, and selfishness in society.

${ }^{23}$ M. Anang Firdaus (43 th), Lecturer of IAIN Fattahul Muluk Papua, Interview, Jayapura, 21 
Through the integration of multicultural values in learning at IAIN Fattahul Muluk Papua the educational process is carried out actively and pleasantly. Lecturers apply the principle of "tut wuri handayani" in every behavior shown by students. The integration of multicultural values in learning at IAIN Fattahul Muluk Papua which is implemented by lecturers builds a learning atmosphere that creates a sense of pleasure and is not indoctrinate, because it begins with an introduction to the meaning of values developed, the lecturer guides students to be active (without telling students that they must be active but lecturers plan to learn activities that cause students to actively formulate questions, look for sources of information and collect information from sources, process information that is already owned, reconstruct data/facts/values, present the results of reconstruction/value development processes) foster multicultural values in students through various learning activities that occur in the classroom.

Briefly, it can be described in a diagram of the implementation of the cultivation of multicultural educational values at IAIN Fattahul Muluk Papua as follows:

Figure 4.7.

\section{The Process of Implementing Multicultural Education Values}

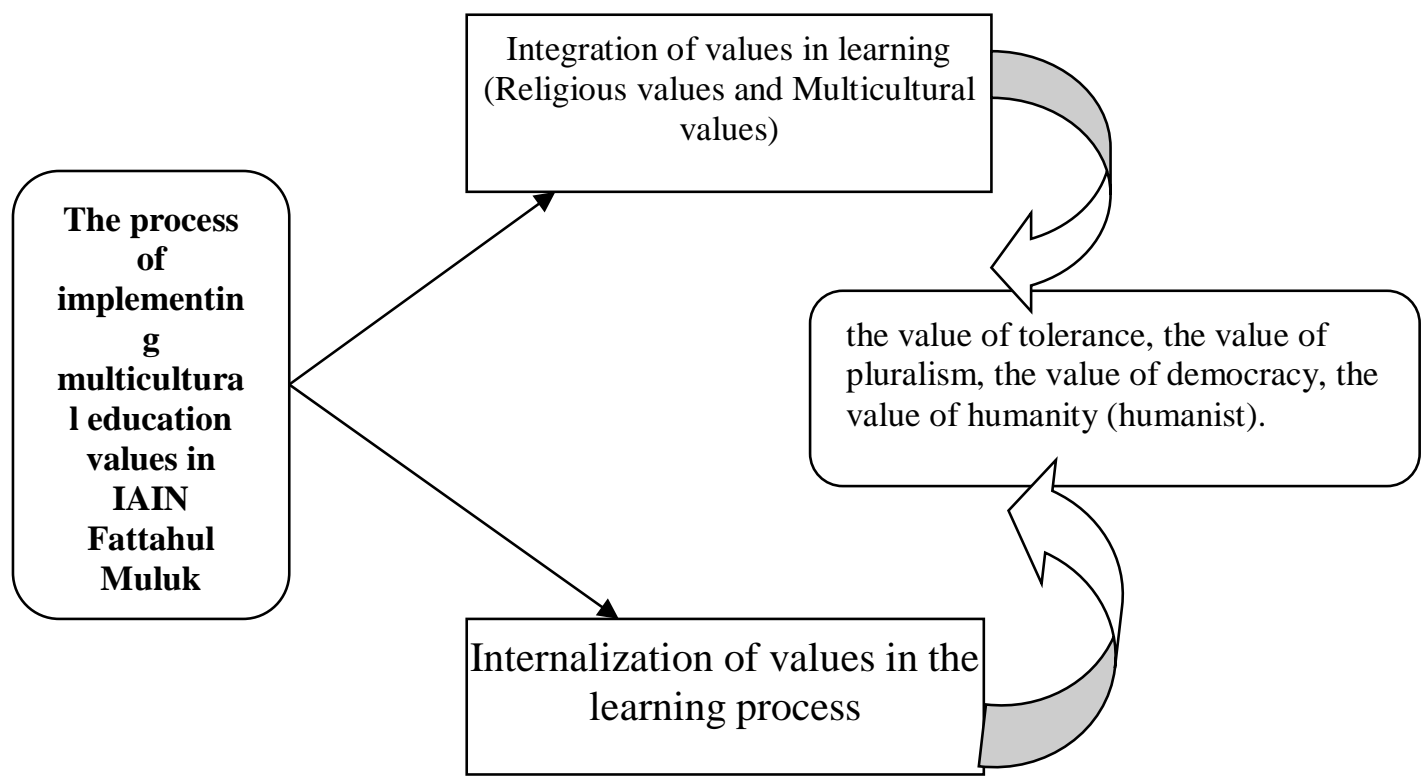

Related to the integration of multicultural values in learning at IAIN Fattahul Muluk Papua, based on the results of interviews and observations it is applied through several values education integration strategies, namely (1) habituation strategy (2) exemplary strategy (3) implicit presentation strategy (4) explicit presentation strategy (5) ) deductive strategy; and (6) inductive strategy.

To clarify the education integration strategy applied in integrating multicultural values in learning at IAIN Fattahul Muluk Papua, researchers obtained data from interviews with several lecturers at IAIN Fattahul Muluk Papua, as follows:

"The implementation of multicultural value integration on this campus is nonnegotiable; this has become the theme of the campus. Although it is realized that instilling and shaping multicultural values is not as fast as teaching skills such as kicking or hitting a ball. This requires a relatively long, consistent, and incomplete process. It could be that students have not fully displayed 
multicultural value behavior as desired. Regarding the application of multicultural value integration, I use two models that are applied. First, forming routine habits filled with multicultural values. Second, implementing role models in instilling multicultural values; the third provides an appreciation for students who display multicultural value behavior. In students, it seems there is no problem, ma'am, on average they have become role models for their students at school, community leaders and others. For our children, students at the sharia faculty I usually apply it.",24

Based on the results of the interview above, integrating multicultural values is not just conveying concepts but is applied through habituation and exemplary which in reality habituation and exemplary are needed in social life. This desire becomes the habitat of humans because imitation and imitation are one of the human traits. The nature of imitation comes from the mental condition of a person who always feels that he is not far away from the same feelings as other groups. So he tends to imitate and emulate other adults, especially the lecturers at IAIN Fattahul Muluk Papua, who are role models in planting multicultural values on campus.

The role of lecturers in facilitating the internalization of values by students includes lecturers as facilitators, motivators, participants, and giving feedback. Lecturers who effectively and efficiently develop their multicultural values who ing ngarso tuladha (in front of the lecturers act as role models/giving examples), ing madya building initiative (amid students, lecturers build initiatives and work together with them), tut wuri handayani (in behind the lecturer gives enthusiasm and encouragement for students).

In integrating multicultural value education in learning at IAIN Fattahul Muluk Papua implementing several other strategies, according to the explanation of interviews with several informants as follows:

"So far, I have integrated multicultural value education in lectures by implementing an implicit presentation strategy, namely the integration of multicultural education, not presenting cultural value education straightforwardly and clearly but disguised and implicit but lecturers as teachers who have analysis sensitivity to the value education phenomenon implicit in it. Every reading, examples, questions, answer, should contain value education. Because value education is not presented explicitly, lecturers and students must look for the right values according to the material, so the lecturer only needs to develop teaching materials by the guidance of places, situations, conditions and needs that contain multicultural values. 25

Departing from the results of the interview, it can be said that the integration of multicultural education is not presented with cultural value education straightforwardly and clearly but is disguised and implied that requires students to develop sensible and structured thinking in analyzing social-environmental problems related to certain values. Things that can be used in this approach are discussions that have directions from the

\footnotetext{
${ }^{24}$ Husnul Yaqin (43 th), Lecturer of IAIN Fattahul Muluk Papua, Interview, Jayapura, 18 Mei

${ }^{25}$ M. Anang Firdaus (43 th), Lecturer of IAIN Fattahul Muluk Papua, Interview, Jayapura, 18
} Mei 2019 
lecturer and have opinions, evidence that can confirm opinions, an affirmation of principles, analyze every problem, conduct debates and even conduct research.

Subsequent interviews with students are as follows:

"Lecturers always integrate multicultural values in lectures by implementing an implicit presentation strategy, namely, students are asked to find their integrated values in learning, usually done directly in class, in my opinion, it is very interesting because ordinary lecturers ask students to look for multicultural values in a reflex-like for example the value of being able to acknowledge, accept and appreciate the existence of other groups and all different traditions and beliefs, and to respect each other. Usually also in the classroom, if students do not get inspiration from multicultural values, the lecturer always develops and prepares noble values in the subject matter according to the context." 26

From the results of the interview, it was found that the lecture process that had been going on so far was quite fun, the lecturer gave them the space to express their opinions, do not discriminate and respect various students. Lecturers interact well with students so that conflicts rarely occur.

The application of multicultural value integration in the learning process through the implicit presentation strategy at IAIN Fattahul Muluk Papua is indirectly the lecturers are integrating multicultural values in learning. It is proven that students feel valued, not differentiated, and allowed to have an opinion. The integration of value education implicitly in IAIN Fattahul Muluk Papua is quite interesting for several reasons. Lectures are more lively and interactive. Lecture material can be used as a stimulant for conducting discussions. With discussion, the learner's analytical power is growing, practicing speaking, processing arguments, and respecting other people's opinions. Learning also becomes varied because the lecturer combines various learning methods and techniques. These materials also provide opportunities for lecturers and students to develop teaching materials by the guidance of places, situations, conditions and needs, even though they are not written in the planning.

Meanwhile, one lecturer explained that when implementing multicultural value integration in lectures, he used a different strategy, namely the strategy of presenting multicultural values explicitly:

Following are the results of interviews with lecturers at the Tarbiyah Faculty of IAIN Fattahul Muluk Papua, as follows:

"The integration of multicultural values in lectures, in my opinion, has become mandatory because it is part of the mandate of our beloved campus, we can see in this campus motto, namely religious, multicultural, and value transformation, so in my lecture as a lecturer, I implemented a strategy of presenting multicultural values in the course explicitly. This means that in lectures, multicultural values are directly instilled in the class as planned, by elaborating on the values that exist in the subject of the planned material choices."27

The results of the interview above emphasize the integration of multicultural values in lectures at IAIN Fattahul Muluk Papua so that students know, understand and

${ }^{26}$ Ahmad Furqon, Islamic Student of IAIN Fattahul Muluk Papua, Interview, Jayapura, 22 Mei 2019.

${ }^{27}$ Nurim Septi Lestari (29 th), Lecturer of Tarbiyah Faculty, Interview, Jayapura, 23 Mei 2019 
can accept values as their own and are responsible for every decision they make through the first stage, namely recognizing their own choices, assessing choices, determining their stance, and confidently implement values. The Tarbiyah faculty has provided Multicultural Education courses in semester 2 with a weight of 2 credits.

The integration of multicultural values in lectures at IAIN Fattahul Muluk Papua, lecturers develop student cognitive by directing students to discuss moral issues to practice theories of moral thinking. In this case, the lecturer approaches from various levels and theories of moral thought. Attitudes that can be used are through group discussions with themes that have been planned in the Semester Learning Plan (RPS). follows:

In connection with the above, the researcher interviewed one of the students, as

"If what I remember in the integration of multicultural values in the class, the lecturer always gave analogous assignments to the subject matter, discussed value education with the manners of life today, practiced value education, observed the phenomenon of character that occurred among adolescents and society, recognized and accepted values. the value that exists in the diversity of persons, sexes, societies and cultures and develops the ability to communicate, share and cooperate with others, and it is often assigned the task of relating these multicultural values." 28

Based on the descriptions of the interviews together with lecturer and students, it can be emphasized that the lecturer applies the strategy of presenting multicultural values explicitly or explicitly in learning Multicultural Education courses. This explicit presentation of value education makes it very easy for lecturers and students to learn multicultural values. Lecturers and students are dynamic, creative, and efficient in developing teaching materials explicitly.

Implicitly or explicitly motivating students to learn multicultural value education which is shown by the ability to analyze various phenomena of value education which are then presented, discussed, concluded, and internalized in students, especially when in a multicultural culture such as in Papua.

Furthermore, the researcher interviewed the lecturers at the Tarbiyah Faculty as well as the Dean, regarding the strategy of integrating multicultural educational values in learning at Tarbiyah, as follows:

"The richness of all the lecturers have tried to integrate multicultural value education in learning at IAIN Fattahul Muluk Papua, because in addition to the demands of the campus, there are also demands in the wider community, especially in Papua, students and society are very heterogeneous both from ethnicity, religion, and language. What I often apply is the integration of multicultural values through a deductive strategy, namely in this strategy, as a lecturer, I convey the core multicultural values first, then students are asked to give examples and then submit as details and examples of the understanding of these values. I apply this technique especially when I teach in the first semester, because the lower the class, the lower the pattern of demands for analytical

\footnotetext{
${ }^{28}$ Lia Yelipele, Lecturer of IAIN Fattahul Muluk Papua, Interview, Jayapura, 21 Mei 2019
} 
thinking. The level of appreciation or understanding of learners is greater than analytical power. I always emphasize the values of fairness in learning." 29

The results of the interview above illustrate that the lecturer implements the integration of multicultural values through deductive strategies, and the lecturer emphasizes the value of justice which is recognition and equal treatment between rights and obligations. The value of justice provides rights that are balanced with obligations or gives someone according to the portion of their needs. For example, in education, parents can be said to be fair if in financing their children's education according to the level of their respective needs, even though nominally each child is not the same number.

After the interview, the researchers continued to collect data through observation in the recovery process of IAIN Fattahul Muluk Papua. The results of the observations are as follows: Lecturers optimize discussion techniques, group work, assignments, role-playing, question and answer, demonstrations, assignments, by minimizing lecture techniques, but empowering and cultivating potential learners. All of these become media in learning multicultural values at IAIN Fattahul Muluk Papua.

The results of the interviews and observations above show that in general, the lecturer has integrated multicultural values in lectures, the lecturer uses multicultural value integration learning steps through deductive techniques.

In the use of deductive strategies, there is consistency in the application of criteria for conducting analyzes of empirical cases which are then returned to their theoretical concepts and consistency in using axioms as a basis for deduction to translate theoretical concepts into application in more specific and operational cases.

If previously the lecturer integrated multicultural values in learning using implicit presentation techniques, explicit presentation strategies, and deductive strategies, then this lecturer always implements an inductive strategy, according to the results of the interview as follows:

"I always apply inductive strategies in integrating multicultural values in lectures, in my opinion, this is very suitable for students, and students look enthusiastic because they are directly involved. For example, as a lecturer, I facilitate material that contains multicultural values from various causes, for example, social action such as conflict resolution, diversity reconciliation, and cultural differences taken from several references such as magazines, newspapers, and including from YouTube. Then the material is given or presented to by students. Often students are also looking for and identifying multicultural values contained in these materials. After that, students describe the identified multicultural values. What is no less interesting is that students conclude the values they have learned together."

From the results of the interview, the application of multicultural value integration in lectures at IAIN Fattahul Muluk Papua through this inductive strategy not only engages students to understand and question social issues but is also involved in doing something important about these issues.

\footnotetext{
${ }^{29}$ Marwan Sileuw (47th), Lecturer of Tarbiyah Faculty in IAIN Fattahul Muluk Papua, Interview, Jayapura, 18 Mei 2019

${ }^{30}$ Nur'im Septi Lestari (29 th), Lecturer of Tarbiyah Faculty in, Interview, Jayapura, 23 Mei
} 
Not only covering, but also adding concrete activities to foster multicultural awareness through the realm of education. From implicit presentation techniques, explicit presentation strategies, and deductive strategies, as well as inductive strategies, it is then that these multicultural education development models can be created so that students understand and can apply these multicultural values with contributive, additive, transformative, or social action.

The integration of multicultural values in lectures at IAIN Fattahul Muluk Papua creates an understanding or awareness and the ability of students to classify their values and assess the behavior of others also needs to be improved. Besides, it helps students use sensible and emotional thoughts in assessing the feelings of themselves or others, their values and attitudes. The methods used in this approach include role-playing, imitation of real events, in-depth analysis of the value itself, activities in class and outside the classroom, and group discussions.

With the integration of Islamic values and multicultural values into the learning process in the classroom at IAIN Fattahul Muluk Papua, students recognize and accept multicultural values as the property of students and are responsible for the decisions they make through the stages of knowing options, assessing choices, determining their stance, and then make value by self-confidence. With this principle, students learn through a process of thinking, behaving, and acting.

The integration of multicultural values in lectures at IAIN Fattahul Muluk Papua improves students' abilities, for example, the ability to analyze and classify values. Besides, the integration of multicultural values in lectures at IAIN Fattahul Muluk Papua is also aimed at increasing the ability of students to carry out social activities and encourage students to see themselves as beings that are always in touch in social life. Steps that can be used in integrating multicultural values in lectures at IAIN Fattahul Muluk Papua are the practice of community life.

In general, the implementation of planting multicultural educational values through the integration of religious values and multicultural education values uses (1) habituation strategies (2) exemplary strategies (3) implicit presentation strategies (4) explicit presentation strategies (5) deductive strategies; and (6) inductive strategy. To make it easier for readers, researchers present in the following image: 
Figure 4.8.

\section{Strategies in the process of integrating multicultural educational values}

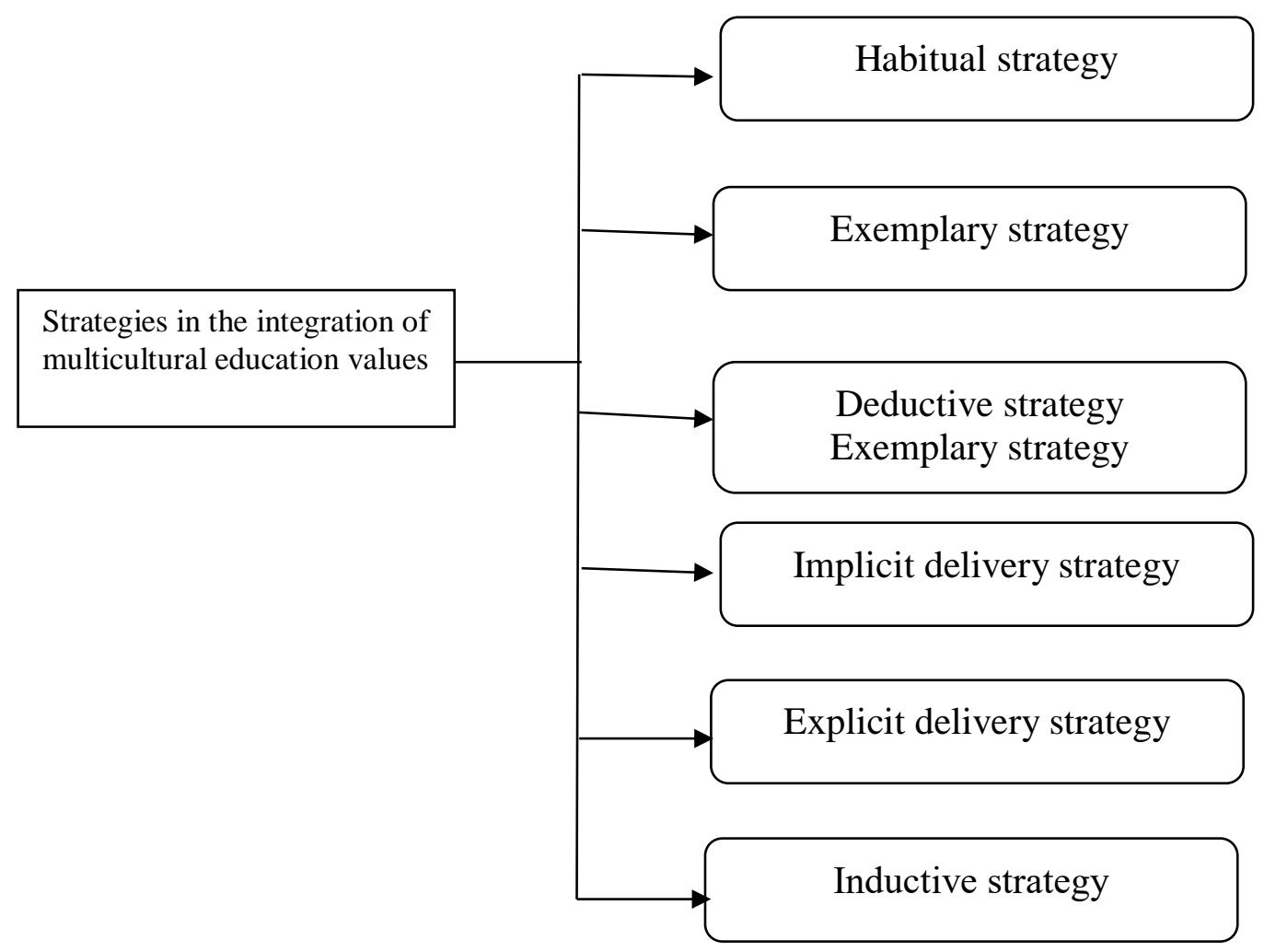

\section{CLOSING}

Based on the explanation above, it can be concluded that the implementation of the cultivation of multicultural education values at IAIN Fattahul Muluk Papua through the first conceptual level is realized through planning and formulating the vision, mission, and objectives of IAIN Fattahul Muluk Papua, the second institutional level is implemented through content integration. education in the curriculum) and the internalization of values in learning carried out by stages (a) transforming multicultural values; (b) multicultural value transaction and (c) the application of transinternalization of multicultural values. The three operational levels include curriculum design that is designed based on multicultural values that are applied through the formal curriculum and hidden curriculum (not included in the curriculum) which is unwritten, not programmatically planned but its existence is influential in the application of multicultural education. The four architectural levels are realized through the formation of an adequate and complete multicultural-based physical environment. 


\section{REFERENCE}

Arief, Armai, Reformulasi Pendidikan Islam, (Jakarta: C3RD Press, 2005), h. 6-7. Lihat pula Armai Arief, Tantangan Pendidikan di Era Global, dalam Jurnal Institut, No. I, thn. 2005.

Banks, James A. Multicultural Education: Historical Development, Dimension, andPractice, dalam Handbook,San Fransisco: Jossey-Bass, 2015.

Maarif, Syamsul, Islam dan Pendidikan Pluralisme; Menampilkan Wajah Islam ToleranMelalui Kurikulum PAI Berbasis Kemajemukan, disampaikan dalam Annual Confrence diLembang Bandung, sumber www.google.com/pluralismependidikan, akses tanggal 22 November 2018.

Muhaimin, Strategi Belajar Mengajar Surabaya, Citra Media, 1996.

Nata, Abudin, Paradigma Baru Pendidikan Islam di Era Pasar Bebas, dalam Didaktika Islamika, Jurnal Kependidikan, Keislaman dan Kebudayaan, Vol. 1, Januari 2015.

Nata, Abudin, Pidato Pengukuhan Guru Besar (Pendidikan Islam di Indonesia: Tantangandan Peluang) UIN Syarif Hidayatullah Press.

Nurhidayati, Yuyun, Multicultural Education in AmericaYogyakarta: Universitas Gajah Mada.

Rasiyo, Berjuang Membangun Pendidikan Bangsa; Pijar-pijar Pemikiran dan Tindakan Cet. I: Malang: Pustaka Kayu Tangan, 2005.

Renstra IAIN Fatahul Muluk 2018-2023.

Yaqin, Ainul, Pendidikan Multikultural: Cross-Cultural Understanding untuk Demokrasi dan Keadilan Yogyakarta: Pilar Media, 2015.

\section{Interview Sources}

Idrus Al-Hamid (47 th), Rector of IAIN Fattahul Muluk Papua, Interview, Jayapura, 11 Mei 2019.

Atinah Rahmah (35th), Lecturer of Akidah Akhlak Tarbiyah Faculty of IAIN Fattahul Muluk Papua, Interview dan beberapa diskusi, Jayapura, 9 Mei 2019

Ahmad Furqon, Student of IAIN Fattahul Muluk Papua, Interview, Jayapura, 19 Mei 2019

Sella Rahmawati, Student of IAIN Fattahul Muluk Papua, Interview, Jayapura, 19 Mei 2019

Warsan (37th), Student of Islamic Postgraduate, Interview, Jayapura, 17 Mei 2019

Talabudin Umkabu (45 th), Lecturer of PAI IAIN Fattahul Muluk Papua, Interview, Jayapura, 18 Mei 2019

Husnul Yaqin (45 th), Shari'ah Lecturer of IAIN Fattahul Muluk Papua, Interview, Jayapura 20 Mei 2019 
Sitti Rokhmah, Hamdan Juhannis,

Muh. Yaumi, Wahyuddin Halim

Nurim Septi Lestari (29 th), Tarbiyah Lecturer, Interview, Jayapura, 23 Mei 2019

Lia Yelipele, Student of IAIN Fattahul Muluk Papua, Interview, Jayapura, 21 Mei 2019

Marwan Sileuw (47 th), Tarbiyah Lecturer of IAIN Fattahul Muluk Papua, Interview, Jayapura, 18 Mei 2019 